\title{
Party spirit: producing a communist civil religion in contemporary China*
}

FRANK N. PIEKE

Mercator Institute for China Studies

Post-print version of 'Pieke F.N. (2018), Party Spirit: Producing a Communist Civil Religion in Contemporary China, Journal of the Royal Anthropological Institute 24(5): 663-891,' available online at https://doi.org/10.1111/1467-9655.12913

The Chinese Communist Party is confronted with a growing gap that separates the rhetoric about socialism and party rule from the individualism and materialism caused by capitalism and opening up to the outside world. In response, the Party has developed strategies that draw on an understanding of the dedication to the Party that is specifically religious, yet does not require belief, conviction, or faith in a doctrine. These strategies revolve around the Leninist concept of 'Party spirit', which, paradoxically, has been turned into a commodity that can be produced, supplied, and consumed. Drawing on insights from the anthropology of pilgrimage, tourism, and religion, these strategies will be discussed in the context of party cadre education and so-called 'red tourism'. The article concludes that the Party is shaping its evolution from an infallible bearer of ideological dogma to a sacred object of worship as part of a new ‘communist civil religion'.

The Chinese Communist Party (CCP) is confronted with a growing gap that separates the rhetoric about socialism and party rule from the individualism and materialism caused by capitalism and opening up to the outside world (Pieke 2016). The reforms have broken down the old socialist collectives and work units, turning society into a collection of indifferent and even hostile strangers. As a result, it is often observed - and not least in China itself - that contemporary China faces a moral crisis and ideological vacuum (Yan 2008). The Party has failed to shore up its legitimacy with anything beyond rising living standards and hollow nationalism, while the CCP's ideological innovations and pronouncements are seen as 
convoluted and stretching the credulity of all but the staunchest believers. According to David Shambaugh (2015), this 'theater of false pretense' fails to provide the moral and ethical guidance that society yearns for, and a crisis of CCP rule should merely be a matter of time.

Although I agree that many ordinary people have little faith in the Party's ideology, it seems unwise to belittle the robustness and political relevance of the Party, especially for, but not limited to, its own nearly 90 million members and cadres. I will argue that the legitimacy of the Party is actually about much more than just policy performance, nationalism, and socialist ideology and ideas. Drawing on the anthropology of religion, pilgrimage, and tourism, I will develop a framework for the analysis of the practice of religion that revolves around the production and maintenance of a sacred domain not against but through the production, deployment, and efficacy of magical power. Using this framework, I will show that the Party has developed strategies to fill the ideological vacuum that build on an understanding of dedication to the Party that is recognizably religious, yet does not require belief, conviction, or faith in a doctrine. These strategies revolve around the Leninist concept of 'Party spirit', which, paradoxically, has been turned into a quasi-magical commodity that can be produced, supplied, and consumed as an aspect of the neo-socialist fusion of Leninist politics and capitalist business practices that has become the bedrock of CCP rule (Pieke 2016). Below, I will investigate this neo-socialist paradox of fostering non-ideological communist dedication through the capitalist commodification of Leninist concepts. I will do so in the context of party cadre education and so-called 'red tourism', where sites and other remains of the CCP's revolutionary history have been turned into tourist attractions. I will then show how this effort is evolving into an element of a new communist civil religion similar to the 'civil religion' in the United States that has borrowed and adapted Christian religious practices for the purposes of a strictly secular worship of the American nation (Bellah 1967). This communist civil religion is not a system of ideas, but a set of practices that produce a habitus (Bourdieu 1977) 
of unquestioned belief in the naturalness and normalcy of the rule of the $\mathrm{CCP}$ without requiring an explicit belief in the rectitude and truth of what the Party's ideology, mission and in what the Party says, does and says it does.

The analysis presented in this article draws on extensive fieldwork at party schools and other educational institutions on cadre training and cadre education conducted between 2004 and 2007 in Yunnan province and Beijing. I have supplemented my fieldwork with extensive documentary research in China, Hong Kong, and the United Kingdom during that period and afterwards (Pieke 2009). In addition, I conducted a fieldtrip to Hongyan (Red Crag) village in Chongqing in July 2015, where I visited and interviewed at the village's red tourism and cadre education sites. I also interviewed party history scholars at Southwest University in the same city on the contemporary significance of Chongqing revolutionary history. After this fieldtrip, I carried out further extensive documentary research on red tourism and cadre education elsewhere in China. At the outset I have to emphasize that this research and my analysis here exclusively focus on the Party's own narrative and strategies. Whether the attempts to instil an acceptance of - let alone a belief in - its right to rule actually have the desired effect on party cadres and the general population is an entirely different question that this article cannot answer. What is certain, however, is that the Party itself invests very considerable resources in cadre education and red tourism and thus seems to be convinced of the efficacy of its approach.

\section{Party spirit under Mao, Deng, and Xi}

The Party currently confronts problems that are in certain respects similar to those faced in the 1960s when Party Chairman Mao Zedong concluded that the Party had been taken over by 
people who 'walked the capitalist road' (zouzi). Mao complained that communist beliefs were being learned from books instead of from labour and revolutionary practice. Cadres abused their power and Party discipline had to be imposed instead of being followed. Mao's solution was to strengthen the personality cult around himself and to launch the Cultural Revolution, which turned the country into chaos and took the Party to the brink (MacFarquhar \& Schoenhals 2006).

Barring exceptional events, such as after the Wenchuan earthquake in 2008, when CCP cadres and members selflessly participated in a massive rescue operation, nowadays real struggle and violence are no longer an option to strengthen the commitment of party members and cadres (Sorace 2016). Instead, synthetic revolutionary experiences, like those that will be discussed at length later on in this article, have been created to take their place. Of course, indoctrination and conformity are also deployed to bring the party apparatus to heel as part of Xi Jinping's political purge and anti-corruption drive. This latter approach revolves around the stern Leninist concept of 'party discipline' (dangji), which lays down the rules of what party members and party cadres should and should not do.

However, indoctrination, commitment, and conformity also have a less heavy-handed side that is summarized by another Leninist concept, namely 'party-mindedness'. This concept is rendered in Chinese as dangxing, which in turn is usually translated into English as 'party spirit' or 'party consciousness'. Party spirit encompasses the unique and unconditional dedication to the Party and its mission. Party spirit first played a prominent role in the CCP's application of Leninist principles after the Wannan Incident in January 1941, a military confrontation between the Communist New Fourth Army and Kuomintang (Nationalist Party) forces that violated the United Front of the two parties against the Japanese occupation. Xiang Ying, the political commissar of the New Fourth Army, who himself was murdered during the incident, was blamed for acting on his own (Benton 1999). To restore unity, the party centre 
concluded that Party spirit education and study were needed throughout the Party. ${ }^{1}$ The CCP's emphasis on party spirit was more widely applied between 1942 and 1944 during the Yan'an Rectification Campaign, which welded the Party into a revolutionary machine under Mao's unchallengeable leadership. Party spirit was further popularized throughout the Party by the book How to be a good communist, the CCP second-in-command Liu Shaoqi's guide for party members, which was first published in 1946 (Sorace 2016). In later years, party leaders have continued to use the concept of party spirit, usually to condemn their foes within the leadership in a call for an end to factionalism and a restoration of unity, for instance by Deng Xiaoping shortly after the start of the reforms in 1978 (Deng 1983: 192).

More than under the previous leaders Jiang Zemin and Hu Jintao, the current leadership under Xi Jinping professes that the Party induces this special spirit, not only as a method to fight factionalism, but also more generally as an antidote to corruption and other types of undesirable behaviour among party members. In a 2014 People's Daily editorial that is widely referred to, Xi Jinping is quoted as saying:

The problem of work style [i.e. corruption and power abuse] is fundamentally a problem of party spirit. To grasp the building of work style we have to go back to basics. The main point is prominent and firm ideals and beliefs, dedication to fundamental purpose, and strengthening moral cultivation (People's Daily 2014).

The emphasis on party spirit is part of a more general and long-term trend of selectively reinventing aspects of the Party's revolutionary heritage. The Party does not just seek a popular mandate based on its governing performance, but is also retooling old-fashioned Leninist and Maoist ideas and practices to foster an unchallengeable dedication to the Party, 
its mission and its rule. Under Mao, the veneration for the Party included not only submission and dedication, but also the worship of Mao himself and the words, deeds, and objects (e.g. the Little Red Book) associated with him (Leese 2011). The emerging official veneration of Xi Jinping in contemporary China takes many of its cues from Mao. Unlike Mao, however, Xi's rule and cult do not eclipse or are not turned against the Party. Despite the increasing concentration of power in his hands and the fawning in the official press over his leadership, Xi Jinping's cult serves the Party, while Xi himself is certainly no Mao Zedong. Similarly, the new emphasis on party spirit is anything but a return to a dark totalitarian past, but an instrument of governance and modernization of the Party.

\section{Pilgrimage, tourism, and party history}

As the sociologist Erik Cohen has demonstrated, religion, civil religion, tourism, and education are often intertwined. In our postmodern world, pilgrimage, religious education, religious tourism, and educational tourism increasingly come together not only to entertain and teach, but also to construct and instil common values and beliefs, and to shape identities and emotional connections to larger communities (Cohen 2006; see also Badone \& Roseman 2004). Eric Wolf, in his early study on the Virgin of Guadalupe in Mexico, had already observed that saints, shrines, or other pilgrimage centres can act as master symbols. They serve as a common focus for social groups or even whole nations, despite the fact that individual members or groups may project very different meanings on to them. Rather than constituting a common cultural core or national character, such pilgrimage sites thus 'provide the cultural idiom of behavior and ideal representations through which different groups of the same society can pursue and manipulate their different fates within a coördinated framework' (E. Wolf 1958). More recently, building on the work of Michael Carrithers and Caroline 
Humphrey, Simon Coleman, in his analysis of the construction of an English Catholic pilgrimage site, developed the concept of 'performative exemplification': that is, using the example to assert the existence of wider wholes whose existence is arguably in doubt. Collecting and combining material remains connected to sacred acts or events invites visitors actively to engage a pilgrimage site in order to tease out its social and moral significance in view of a wider whole. It is indeed this interpretative work of such an example of a larger enterprise or belief system that makes the visit an interesting and rewarding learning experience, despite, I would like to add, the often very careful guidance and framing provided (if not imposed) by the keepers of the site (Coleman 2015: 149).

However, sites, shrines, and objects are more than mere tokens or examples. They are thought to possess a spiritual power that mediates between the sacred religious and the profane worldly domains. In Mircea Eliade's evocative interpretation, pilgrimage centres constitute sacred places set off from the profane space around them because of the permanent nature of the manifestation of the sacred that first occurred there. This power has an efficacy that pilgrims and tourists hope will heal, enlighten, destroy, or have any other magical impact on the ordinary world (Eliade 1958; for Chinese examples, see Sangren 1987). Combining the insights of Mircea Eliade and Eric Wolf, John Eade and Michael Sallnow write that shrines and pilgrimage centres have multiple meanings that nevertheless appear universalistic because of their capacity to offer a variety of clients what they desire: '[I]n a perfect example of the classic Marxist model of fetishization and alienation, the shrine then appears to its devotees as if it were itself dispensing the divine power and healing balm which they seek' (Eade \& Sallnow 1991: 17-18; see also Coleman 2002).

The words and material remains that serve as tokens of the Party's revolutionary deeds are much like the objects, remains, and miracles associated with, for instance, Catholic saints in the context of pilgrimage (Harris 1999). 'Red' sites where important revolutionary events 
unfolded have been turned into sites of learning and tourist attractions. Although the word 'heritage' itself does not occur in this context, the Party has enlisted commercial strategies of the blossoming tourism and cultural heritage industry in China to commodify and market party spirit, serving the reproduction of the commitment to the Party not only by the general population but also among its own cadre corps. Heritage, including revolutionary heritage, is a selection from what remains of the past to create meaningful tokens of belonging in the present. Producing heritage is an act that simultaneously involves remembering, forgetting, preserving, and fabricating. Heritage production turns history and culture into commodities whose authenticity is validated by a certain authority and can be consumed as part of tourism, education, training, or leisure (Hewison 1987; Shepherd \& Yu 2013).

Like pilgrimage centres, red tourism sites serve as nodes where the sacred power of the Party becomes accessible. More generally, pilgrimage and tourism (red or other) are similar in that they entail specific events that, through the act of travelling, the absence of work, and the distance from ordinary life, create a special period of time and experience distinct from the normal and mundane. Like rites of passage that facilitate a temporary leave from the ordinary in order to achieve a change in the participants' social status, pilgrimage and tourism create a non-ordinary state of being where special things can happen, a period of time set apart from ordinary life. Pilgrimage and tourism alter their participants, reinvigorating their belief, recharging their energies, renewing their sense of purpose, or sometimes even enabling a change to another kind of life. Most importantly, a rite, pilgrimage, or touristic trip matters most afterwards upon return back to ordinary life and the people in it. As we shall see below in the context of red tourism in China today, it matters less what has actually happened while away (which might actually have been quite mundane, contrived, or disappointing). What is important is the fact that one has been away, returning with tokens of exposure to something special: a bodily alteration (a tattoo, hairdo, or even just a suntan), an item of clothing, a 
souvenir or other object, a selfie, a photograph or video, a social media posting, or just stories to tell (Graburn 1977; Turner \& Turner 1978).

\section{Party spirit and red tourism}

Sites and objects associated with the history of the CCP's revolutionary struggle, and especially with the words and actions of the Party's major leaders, have been preserved for a

long time, in some cases as far back as the $1950 \mathrm{~s}^{2}$ Tourism at these sites has been encouraged for almost as long. However, the Cultural Revolution (1966-69) was a watershed. During that period millions of Red Guards travelled across China to 'link up', learn from each other, and strengthen their knowledge and dedication to socialism, the Party, and the revolution. They travelled to the sites of the Chinese revolution, to model communes, and of course to Tian'anmen Square in Beijing to see Chairman Mao with their own eyes. Although there is no direct connection between Red Guard revolutionary travel and current mass tourism, the Party's belief in the efficacy of visiting sacred sites and the importance of mass travel across the country to trace and re-create the nation and the revolution clearly dates from this period.

After the Maoist period, memories of the 'red culture' have been developed and exploited for a range of purposes, both commercial and political. The Mao fad of the 1990s, for instance, was for many people more than just nostalgia. Memories of the Maoist period could also be a way to express dissatisfaction with the materialism and inequalities of the reform period in a language that the Party found difficult to object to. At the same time, Mao badges and other Maoist memorabilia quickly became highly prized collectible commodities, turning nostalgia into a commercial proposition (Barmé 1999, chap. 12; Hubbert 2006). 
'Red legacies' have now become an integral part of the cultural, commercial, and political landscape. However, red restaurants, red books, red films, red art, or other forms of red culture are not just capitalized on as an alternative to the dominant consumer culture. The CCP has been quick to reappropriate red culture for its own purposes (J. Li \& Zhang 2016). From the early 1990s onwards, as part of the patriotic education campaign that followed the suppression of the 1989 protests in Tian'anmen Square and elsewhere, selected CCP history sites were included among the 'patriotic education model bases' (aiguo zhuyi jiaoyu mofan jidi) designated to strengthen loyalty and respect for the nation and the communist revolution (Callahan 2010; Zhao 1998). ${ }^{3}$ Continuing on from this effort, the systematic and centrally coordinated project to list, restore, and build sites of CCP revolutionary history specifically as 'red tourism' (hongse lüyou) bases started in 2004. In that year, a national meeting on red tourism development planning was held at which then CCP propaganda chief Li Changchun gave a keynote speech. Subsequently, the CCP Central Committee and the State Council jointly issued a red tourism development planning document for 2004 to 2010 (Denton 2014, chap. 10; Y.P. Li, Hu \& Zhang 2010; Takayama 2012). According to the planning document, red tourism had to become a policy priority area for the central party and government (National Development and Reform Commission 2004). Further five-year development plans have been issued for the periods 2011-15 and 2016-20. At the central level, red tourism has its own 'co-ordinating small group' (xietiao xiaozu) that currently meets annually. The group is chaired by the deputy head of the powerful National Development and Reform Commission with representatives from fifteen or so central ministries, bureaus, offices, and companies in attendance (China National Tourism Administration 2015).

Red tourism deploys significant places and objects associated with events during the revolution as bearers of revolutionary history, revolutionary events, and revolutionary spirit for tourists to recall, study, and observe. Since his accession to power in 2012, Xi Jinping, 
too, has fully committed himself to the idea of red tourism. According to an article in the authoritative Guangming Daily (Guangming Ribao) on the general secretary's expositions on the topic, Xi has said that 'as far as we Communists are concerned, China's revolutionary history is the best nutrient'. The article explicitly connects the exposure to revolutionary spirit at red tourism sites to 'socialist core values' and the 'dream of the great rejuvenation of China', key indices of the Xi Jinping era for the Party's refurbished ideology, mission, and right to rule.

In a further discussion of the effects and functions of red tourism, the Guangming Daily article goes on to quote $\mathrm{Xi}$ that

developing the study and teaching function of red tourism will solve the problem of patriotism and belief ... In the course of the touristic process, guests will come to understand the history of the glorious struggle of the Chinese revolution, strengthening patriotic sentiments and confirming ideological belief (Guangming Daily 2014).

Red tourism exposes the tourist to the revolutionary spirit of the deeds of legendary leaders embodied in sacred sites and objects. Such exposure is intended to bring forth not explicit and reasoned conviction, but feelings and attachments that yield implicit belief. Commitment to the Party has become an engineered dedication that speaks directly to the soul; red tourism has become a form of pilgrimage in all but name.

A collection of poems on display at red tourism sites that was published in 2013 lists no fewer than 123 such sites. Together, these sites present a narrative of the revolution consisting of twelve phases from 'the birth of the Party' to 'the final victory' (Yu 2013). The ideas, language, and techniques of red tourism have been dismissed both inside and outside of China 
as mere propaganda, or have even been ridiculed as artificial and contrived, as, for instance, was done by Chinese netizens with the opening of a brand-new Communist Party theme park in Wuhan in October 2015 (Phillips 2015). Yet despite this cynicism, red tourism and patriotic education have become a major industry. According to official figures, already in 2007 red tourism sites drew a total of 230 million visitors, who mainly travelled in groups organized by work units or schools. By 2008, an estimated RMB 1.86 billion of government funding had been allocated to 181 red tourism-related projects; in addition, RMB 59.8 million private funding had been invested. These investments are clearly paying off (Y.P. Li et al. 2010: 106). In 2013, the number of visitors to red tourism sites had gone up to 786 million. Red tourism in that year generated an income of almost 2 billion yuan, directly employing 1.22 million people and indirectly employing another 460,000 (China National Tourism Administration 2014; Y.P, Li et al. 2010).

Despite the appearance of a return to old-fashioned communist practices, the business and politics of party spirit reveal all the trappings of modern-day neo-socialist governance: a capitalist market that is not merely tolerated by a communist party, but is actively deployed to shore up and develop its Leninist political system. Under neo-socialism, markets have been created for a vast range of commodities, resources, and services previously provided and controlled by the state. These include not only social security, housing, education, or health care. The Party has turned even support for and attachment to itself into a transferable commodity. Moreover, because many of the events of the revolution took place in remote areas, red tourism is often developed in conjunction with ecological ('green') tourism and presented as a way to reduce poverty and enable ecologically friendly development in marginal regions (H. Wang 2014; Xu 2010). In official documents, red tourism is presented as firmly rooted in the present and confidently looking forward to a bright and enduring future for China and the Party. It showcases the Party's commitment to the market economy, 
economic growth, revolutionary mission, innovation, and fair and sustainable development all at once: a perfect example of how the Party would like to be seen (China National Tourism Administration 2014; 2015; Guangming Daily 2014).

\section{Party spirit and cadre education}

In cadre education and training, the Party takes its own elite as its object. Moulding and managing China's administrative elite is crucial in keeping the Party on message and fit to rule the country. Cadre education and training thus serve two quite different objectives: ideological conformity and professional competence. Education and training include management and leadership skills in addition to more general or vocational subjects like economics, international relations, military affairs, law, accounting, history, philosophy, and English. However, many cadres continue to find policy and to a lesser extent ideology equally relevant. Their jobs and promotions continue to depend on their ability to sift 'correct' from 'incorrect' ideas and approaches: that is, ideas that have been endorsed by those currently in power in Beijing from those of their rivals or enemies (Lee 2015; Pieke 2009).

Although reading and study of communist theory were a part of the curriculum at party schools in the early 2000s, the Party and its leaders were not presented as objects of reverence, devotion, or faith. This, however, has changed. The most recent (2013-17) plan for cadre education and training emphasizes more than previous plans the importance of cultivating party spirit and the vital role that studying the revolutionary history of the CCP and its leaders should play in forging dedication to the Party: 
The party's spirit, direction and discipline and party national history education must vigorously be strengthened. Party members and cadres must take the party constitution as a fundamental standard for strengthening party spirit. Party discipline, especially political discipline, and cadres' adherence to the Party's basic theory, line, programme, and experience have always been vital for the party centre under Xi Jinping in order to resolutely safeguard its authority and to ensure that the central government decrees remain unimpeded ... Party and national history should become a mandatory part of cadre education. This will help cadres to understand the development of the Party and the country and will give them a profound understanding of the experiential lessons the Party has drawn (People's Web 2013).

Emphasizing party discipline and fighting corruption are part of Xi Jinping's efforts to gain control over the party apparatus, and as such are relatively straightforward. However, cadres are also told that in order to learn how to be a good cadre and a good communist they should not simply follow orders. They are not the ordinary masses or soldiers after all, but leaders, the embodiment of the Party suffused with its special nature or spirit. Party spirit turns cadres into autonomous and disciplined agents to be trusted as 'comrades' rather than personal friends, clients, subordinates, or lackeys.

In part, party spirit can be learned from the study of the written work of communist leaders. Mostly, however, it must be gained from the study of and exposure to what the Party and its leaders have done in the course of the CCP's long and tortuous history, a method that could be called second-hand revolutionary practice. An important pedagogy to achieve this is what the CCP calls on-site learning (xianchang jiaoyu). Places for such on-site learning are specifically designated locations developed to accommodate visits by groups of cadretrainees. ${ }^{4}$ 
In the development of 'bases for cadre education about the Party's spirit' (ganbu dangxing jiaoyu jidi), the central authorities took the lead in 2003 when they decided to establish and fully fund three completely new, high-profile cadre academies (ganbu xueyuan, officially translated as 'executive leadership academies') that opened in 2005. These academies are located in Shanghai, the place where the Party was founded, but more importantly also the pinnacle of China's modernity and international opening up; the sacrosanct revolutionary sites of Jinggangshan, the first base area and the 'cradle' of the Party; and Yan'an, the base area from where Mao launched the Party's conquest of China. Together, these three sites offer a carefully constructed, material representation of the Party's auto-narrative of its own birth, growth, and maturation on which the academies offer an 'experiential education' (tiyanshi jiaoyu)..$^{5}$

\section{Hongyan and the commodification of party spirit}

In addition to the three cadre academies, since 2010-11 the Central Organization Department has recognized (but not funded) nine more bases for party spirit education, making for a total of twelve such centrally recognized sites. In addition, over sixty further sites have been established by provincial or other lower authorities to cater for the needs of their own cadre education plans. None of these sites have received central recognition, let alone funding. They principally serve local needs and support a local narrative on the revolution. ${ }^{6}$

The effort to build up party spirit education bases sounds impressive until one realizes that virtually all party spirit cadre education bases are established sites on China's red tourism trail. Only the three central cadre academies have been purpose-built. The recent surge in cadre party spirit education uses the existing infrastructure of red tourism, adding to it further 
investment and elaboration at selected sites for a more discerning clientele of cadres. During fieldwork at one such site, Hongyan (Red Crag) village in Chongqing in July 2015, the party secretary of the village flatly stated to me that cadre education at Hongyan 'uses a tourist site as a teaching site' (yong lüyou zhi dian wei jiaoyu zhi dian). Educational visits to Hongyan usually last half a day of 'on-the-spot observation' (xianchang guancha), but Hongyan also offers programmes of a full day or more, depending on the requirements of the organization that has commissioned the training. Visits to Hongyan are a mandatory part of training for Chongqing cadres, of whom Hongyan receives between 10,000 and 20,000 annually. In addition, between 1,000 and 2,000 cadres from elsewhere visit, mostly from party schools with which Hongyan has a reciprocal relationship. ${ }^{7}$

Hongyan village was the location of the CCP's Southern Bureau (Nanfang Ju) during the Japanese occupation when the government of the Nationalist Party (Kuomintang, KMT) had moved to Chongqing (1937-46). Headed by Zhou Enlai, the Southern Bureau had to operate very carefully, navigating between co-operative relations with the Nationalists as part of the United Front against the Japanese and the reality of increasing animosity and sometimes even open armed conflict elsewhere in China between the two parties. Party history as narrated by officials and official sources in Hongyan and elsewhere in Chongqing emphasizes the unique nature of 'the contributions of the Hongyan essence to the system of the Party's revolutionary essence' (Hongyan jingshen dui Zhongguo geming jingshen tixi de gongxian). This is glossed to mean that, unlike other key revolutionary sites such as Yan'an, Jinggangshan, Zunyi, and Xibaipo, where the Party's spirit was forged in communist base areas or in the armed forces, the leaders of the Southern Bureau operated openly in territory ruled by the Kuomintang. They had to make endless compromises and deal with all sorts of non-communist forces. In the language of CCP historiography, they 'emerged from the mud unstained, having joined bad elements but not shared their evil practices' (chu yuni bu ran, tongliu bu hewu). In terms 
of its contemporary relevance, the unique experience in Hongyan is the origin of the CCP's later co-operation with the eight patriotic democratic parties and non-party elements; China's peaceful and pragmatic foreign policy (exemplified by Zhou Enlai); and co-operation between the CCP on the Mainland and the Kuomintang (KMT; Nationalist Party) on Taiwan to unify the fatherland. ${ }^{8}$

Hongyan village is one of China's prime red tourism sites. Back in 1958, the original building of the Southern Bureau was turned into a museum called the Hongyan Revolutionary Remembrance Hall (Hongyan Geming Jinianguan). In 2002, the hall was renovated and redecorated. In 2013, a new exhibition hall was added, including a spacious lecture theatre for about 150 people befitting the purposes of cadre education. ${ }^{9}$ The Revolutionary Remembrance Hall's displays include photographs, manuscripts, and calligraphy, newspaper clippings, historical footage, paintings and portraits of historical figures, and even the old printing press of the Liberation Daily (Jiefang Ribao), the CCP's main newspaper at the time. Some of the materials in the museum are originals (such as bound copies of the Liberation Daily saved from a scrap paper dealer in the 1960s), but most are reproductions or pieces specifically commissioned for the exhibition. The exhibition strongly foregrounds the legendary leaders of the CCP - especially Zhou Enlai - and what they have said and written; the other items mainly serve to contextualize these. This is quite different from the original building of the Southern Bureau, which has been very carefully reconstructed to reproduce the original look and feel of the rooms, furniture, decorations, and even an old telegraph machine. Here the emphasis is on the leaders (including Mao himself for a period in 1945 during the failed negotiations with Chiang Kai-shek after the Japanese surrender) as individual human beings who lived and worked in times of great adversity.

Even newer than the exhibition hall is the China Democratic Parties History Exhibition Museum (Zhongguo Minzhu Dangpai Lishi Chenlieguan). The democratic parties are part of 
the United Front that the CCP put together after the Second World War in its fight against the Kuomintang. The United Front and the democratic parties have continued to exist after Liberation in 1949 as part of the consultative structures that were added to CCP one-party rule. After the start of reforms in 1978, this multi-party edifice has again been given greater importance. As the Kuomintang's wartime capital, Chongqing claims to be the birthplace of the United Front, celebrating the role of the democratic parties as an essential part of the CCP's auto-historical narrative.

The Democratic Parties Museum is located about a ten-minute drive from Hongyan village at the site of several former foreign embassies during the Japanese occupation. The museum is managed by Hongyan in co-operation with the CCP's United Front Department in Chongqing. As is the rule with public buildings dedicated to United Front work, this museum is even larger and more luxurious than the Hongyan Revolutionary Remembrance Hall itself, but is otherwise similar in nature: the museum primarily conveys a specific political message. The displays are arranged separately for each of the eight democratic parties with additional displays for the Association of Industry and Commerce (Gongshanglian) and non-party political figures. The primary focus is on individual historical personages and events mainly narrated through historical photos and texts, the latter including newspapers, speeches, and writings.

A further and very important revolutionary history site is the Gele Mountain Museum (Gele Shan Bowuguan). It main site is the Exhibition Hall of the Soul of Hongyan (Hongyan Hun Chenlieguan). It was built in 1963 in dedication to the memory of communist revolutionaries victimized by the Nationalists. The history celebrated here is thus very different from the one at Hongyan village. The execution and torture of communist prisoners were made famous by the 1961 novel Hongyan (Red Crag), which implicated the Sino-American Co-operative Organization (SACO), an organization established in 1942 for sharing intelligence between 
the American and Nationalist Chinese governments, in the atrocities that took place. Although this most likely is historically incorrect, blaming the Americans for complicity with KMT brutality was a very effective anti-American propaganda tool during the Cultural Revolution. ${ }^{10}$ In addition to the Hall, the Gele Mountain Museum also includes the Gele Mountain Martyrs Monument (Gele Shan Lieshi Lingyuan) and two KMT prisons, White Villa (Baigong Guan) and Refuse Pit (Zhazi Dong). At these former prisons, tourists can watch theme park-like displays featuring torture scenes of communist prisoners. In 2008, the exhibition of the museum was upgraded and moved to a new, modern building. ${ }^{11}$

The Hongyan Remembrance Hall and the Gele Mountain Museum are not only separate sites serving separate histories, but also separate organizations. However, their commercialization has been conducted jointly under the dynamic leadership of Li Hua, who until 2011 was director of both. According to a report posted by Li on a website dedicated to red tourism, for more than ten years before the start of the official red tourism strategy in 2004 , he already had organized exhibitions, lecture tours, performances, and meetings across the whole country. His objective was to turn the 'Hongyan soul' (Hongyan hun) into what he called 'the largest revolutionary brand of the country' (H. Li 2004). Li himself got as far as being a delegate at the 2002 National Party Congress.

Since April 2004, the two organizations have formally worked together in the Chongqing Hongyan Alliance Culture Development and Management Centre (Chongqing Hongyan Lianxian Wenhua Fazhan Guanli Zhongxin). The Centre was established together with several other smaller revolutionary education bases and cultural scenic spots in Chongqing, presumably to take full advantage of the new national red tourism strategy mentioned earlier that would be announced later in the same year. According to Li Hua, the objective was 'to join forces to package and market the Hongyan brand' (H. Li 2004). Subsequently, the Centre spun off its money-making activities into a separate commercial entity called the Chongqing 
Hongyan Culture Business Group (Chongqing Hongyan Wenhua Chanye Jituan). In order to attract more business, in 2007 the two organizations built and opened the Hongyan Revolutionary History Museum (Hongyan Geming Lishi Bowuguan).

As per national policy, entry to red tourism museums was made free of charge in 2008, but red tourism has remained good business nevertheless. The museums get paid for guided tours, courses, and events that they organize for visiting groups of cadres or tourists, and sell souvenirs, produce performances, and release DVDs of theatre, dance, and music. Red tourism visitor numbers in Chongqing have been growing fast, from 3 million in 2008 to 6.5 million in 2010 (H.Z. Wang 2011); as mentioned earlier, the number of cadre visitors in 2014 was reported to me to be merely in the order of 10,000 to 20,000 . Despite this relatively modest number, cadre education lends greater credibility to red tourism sites like Hongyan, while itself profiting from the existing infrastructure of red tourism. Red tourism and cadre party spirit education thus benefit from each other. Both are based on the same premise, namely that the Party's history and unique character can be transformed into transferable commodities to be consumed for different purposes and by different client bases. ${ }^{12}$

\section{The politics of party spirit}

Party spirit in red tourism and cadre education is not just a commercial commodity, but also a political commodity. Commercial and political considerations often chime very well with each other, but sometimes they won't. Local authorities, organizations, and individuals develop revolutionary history sites as much to suit their political objectives as to make money. The development and significance of sites is also subject to the shifts and changes of Communist Party politics. The current prominence of the Xibaipo site illustrates this very 
well. Xibaipo was the base in Hebei province from where the CCP leadership directed the military campaign during the Civil War with the KMT between 1946 and 1949. The development of Xibaipo as a red tourism site was mainly due to the patronage of supreme party leaders Jiang Zemin and Hu Jintao in the 1990s and 2000s. They appropriated the 'spirit' of Xibaipo to emphasize the importance of building a new China over the Maoist enterprise of making revolution (Denton 2014: 238-42).

Hongyan happens to be located in Chongqing, a municipality that was recently the focus of the most important confrontation among CCP leaders since the Tian'anmen demonstrations in 1989. This presents us with an opportunity, albeit small and partial, to see the politics of the commodification of party spirit in action. In 2011, Li Hua was stripped of his posts as director of the Hongyan museums. Some of this may have had to do with suspicions that he was abusing his power, such as the excessive price of 500,000 yuan he paid in 2009 to purchase some offprints of photos from the war period. ${ }^{13}$ However, the timing of his fall in 2011 makes it very likely that Li and with him Hongyan had become caught up in what became a very high-profile national power struggle.

In 2008, Li's project to turn the Hongyan soul into China's largest revolutionary commodity received a huge boost when Bo Xilai, a major political figure in Beijing at the time, was sent to Chongqing after losing to Xi Jinping at the 17th Party Congress in 2007 in his bid to become frontrunner for the election of the Party's new general party secretary at the next congress in 2012. Tapping into the widespread nostalgia for the Maoist period discussed earlier, Bo promoted a 'red culture' in Chongqing that explicitly borrowed from Maoist practices, for instance the requirement for cadres to live, work, and eat with the peasants, or the collective singing of red songs. ${ }^{14}$ The emphasis on China's red revolutionary past chimed very well with Li Hua's promotion of the Hongyan soul. Li quickly became even more prominent than he already had been, with Bo Xilai going as far as saying that 'Chongqing 
needs ten Li Huas! ${ }^{15}$ Hongyan and Li Hua quickly gained further national prominence. In June 2011, China's premier English-language newspaper, the China Daily, ran an article on Hongyan's successes. In the article, the Group's director (unnamed but presumably Li Hua) confidently stated that ' $[\mathrm{t}]$ he sector is ready to be expanded and we have engaged consultants to help restructure the Hongyan Culture Business Group to be qualified to be listed [on the stock market] in three years'. The article went on to quote a policy researcher at the China Tourism Academy in Beijing saying that 'the market will take over the role of the government in future in driving the development of red tourism, as is already happening in Chongqing' (H.Z. Wang 2011).

In 2012, however, Bo Xilai paid the price for his rivalry with Xi Jinping. He was accused of corruption and sentenced to fifteen years in jail. Shortly afterwards, Xi was elected CCP general party secretary. After Bo's fall, Li Hua disappeared from view, although as a local Chongqing cadre without specific factional ties to Bo he seems to have escaped a full-fledged purge. Hongyan's national prominence also suffered, but only temporarily. At the Centre in Beijing, China's role and suffering during the Second World War have become a major plank of Xi Jinping's strategy for a more prominent role of China in the East Asian region and globally. This new prominence of the war effort includes not just the CCP itself, but also a reassessment of China's role as a whole. Although the efforts of the CCP during the wartime period continue to be highlighted, more room is given to the contributions of the Kuomintang, which had been belittled for so long, even including those of the KMT's leader and the CCP's old arch-enemy, Chiang Kai-shek (Jiang Jieshi). ${ }^{16}$ Chongqing has been quick to avail itself of the opportunities this provides to showcase the city as a site of national historical importance unconnected to Bo Xilai's red culture and directly relevant to the political priorities of the current leadership in Beijing. With the CCP again tapping into the messages that Hongyan 
conveys as part of China's wartime effort and suffering, the spirit of Hongyan is sure to continue to play a prominent role.

In red tourism and cadre education, the construction and significance of the sacred is strongly prescribed, contained, and enforced. Tourists and students might very well be able to project their own readings and desires on to them, as we saw that Eric Wolf, Simon Coleman, and postmodern writers like John Eade and Michael Sallnow have found at pilgrimage sites, but they have to do so against the full force of one of the most dominant and powerful institutions in the world: the Chinese Communist Party. Nevertheless, red tourism and party spirit education, as we have seen, are not simply rolled out across China by central diktat, but are deeply political and connected with competition and conflict within the apparatus of the partystate. We might therefore conclude that, although the potential multivocality of pilgrimage is thus not fully repressed in red tourism and cadre education, it resides principally with the producers instead of the consumers of the sacred.

\section{The magic of instilling communism}

We started this article with the concept of party spirit (dangxing), an undifferentiated and almost abstract quality without concrete form or specific characteristics entailing the absolute dedication to the Party and its ideology. At Hongyan and other revolutionary heritage sites, this quality has been transformed. In the course of its revolutionary history, the Party and its leaders were charged (possessed?) with the party's spirit, enabling them to face unimaginable hardship, make tremendous sacrifices, and, above all, take sagacious decisions that ordinary men and women would not have been capable of. Exposure to the record and remnants of their revolutionary deeds turns this general spirit into a concrete and transferable quality that 
is usually referred to as jingshen (and less frequently hun, 'soul'), which I translate here as ‘essence' or 'efficacy'.

Dangxing and jingshen have very different implications. Dangxing makes the Party and its mission sacred and above ordinary human experience and affairs. It is a transcendental but largely passive quality that is inherent in the Party without having a specific origin, source, or direction. Dangxing should be studied, emulated, cultivated, or restored, but it has no agency of its own. Jingshen essence, however, is presented as an active force that affects people, institutions, words, and deeds. In doing so, jingshen essence straddles the line dividing the sacred and the profane. Jingshen is a spiritual force that can be deployed in the commercial and political arenas. It can be transferred to ordinary humans, inspiring awe of and dedication to the Party, and to ideas, policies, choices, and actions, rendering them sacred and beyond doubt. The application of jingshen is thus a concrete and practical activity that has much in common with magic: that is, activities that compel supernatural forces to behave in a certain way in order to achieve specific and desired effects in the human, natural, or supernatural world. A quote from Xi Jinping serves to illustrate the power of jingshen.

Every visit to Jinggangshan, Yan'an, Xibaipo, or another sacred revolutionary place is a spiritual (jingshen) and ideological baptism. Every time I come there I receive vivid education in the Party's nature (dangde $x i n g z h i^{17}$ ) and mission, again confirming the awareness and feelings for the people that we as public servants (gongpu) have (S.M. Wang \& Liu 2014).

The Party's essence thus becomes an efficacious magical power that transforms those who are exposed to it. However, there is a further, neo-socialist twist: this transformative magical 
force can in turn be turned into a discrete and transferable commodity. The sacred time of tourism and on-the-spot experiential education enables the release of the productive power of party jingshen, a world apart from the diffuse and sterile party dangxing that may be gleaned from the Party's revolutionary record, which one can learn about at home, in school, or elsewhere during one's ordinary life. Indeed, jingshen can be thought of as the Party's sacred essence as it resides in concrete historical words, deeds, objects, or sites. It has the power to change or transform ordinary people and events. Exposure to these material remains of the Party's history charges tourists or students with the Party's essence, which manifests its sacredness in the ordinary world and reinvigorates dedication in the Party and its mission. Party spirit and party essence in contemporary China are not red herrings. They are serious politics and serious business at the core of the Communist Party. Like religion, socialism and communism require conversion and unquestioned belief in dogma, and provide a full eschatology that gives sense and purpose to what has to be done here and now. However, simply viewing these ideologies as 'secular religions' (cf. Aron 1957) would be one-sided, because such an interpretation is predicated on a Western, secularist understanding of religion modelled on the Protestant and Catholic Reformations of Christianity. Religion in the secularist worldview ought to be a private belief and an internal state of mind that has no place in the other, secular spheres of society, and more particularly politics and the state. Ostentatious rituals and other practices that guide and influence the interaction with the supernatural are considered non-essential or even dubious ornamentations that belong to magic or 'primitive' religion, but have no place in civilized religion in modern societies (Casanova 1994; Taylor 2007).

Such a 'disenchanted' (Weber 1946) view of modernity blinds us to some the most salient aspects of religion, not only in premodern but also in modern societies. Cross-culturally, religion is not necessarily about dogma, conversion, and belief at all. First of all, religion as a 
lived-in practice does not come from a personal conviction of revealed truth, but is about the privileging of certain aspects of one's environment, life, and experience as sacred: that is, as special and set apart from what are thought to be the normal, profane domains of life. This distinction exists in any society quite independently from what it is that is believed in and what exactly it is that is considered sacred (Durkheim 1965 [1912]).

Second, religion is as much about the belief in the efficacy of what religious forces or entities can do, both in the supernatural, natural, and human domains of experience, as it is about what exactly it is that one believes in. This latter, practical aspect of religion is best captured by the term that I have used throughout this article: magic. I do not wish to delve into the long history of anthropological debates on the differences and connections between religion, magic, and science and their purported rationality or irrationality (e.g. Evans-Pritchard 1965; Tambiah 1990). Here I understand magic simply as the manipulation of supernatural powers to influence the world. As Durkheim himself acknowledged, religion and magic are often hard to distinguish, despite the hostility they often hold against each other: 'Magic takes a sort of professional pleasure in profaning holy things' (1965 [1912]: 58). This fairly offhand comment does in fact constitute a crucial insight into what we could call the efficacy of the sacred. Magic straddles the dividing line between the sacred and the profane. As the profane efficacy of sacred practices, magic is inherent to all religion. In Lévi-Strauss's words: 'There is no religion without magic any more than there is magic without at least a trace of religion. The notion of a supernature exists only for a humanity which attributes supernatural powers to itself and in return ascribes the powers of its superhumanity to nature' (1966: 221). In other words, magic and religion are not each other's antitheses. They are two sides of the same coin and need and condition each other. Religious beliefs define a sacred supernatural sphere that makes magic possible and efficacious. Magic in turn has the power to invoke religion because it manifests the supernatural in nature, and conversely it is an instrument for profane actors to 
influence the supernatural. It is about practice rather than theology, and as such is an essential component in the practical generation of religion as habitual rather than doctrinal belief (see also Greenwood 2009; Styers 2004).

The evidence presented in this article shows that the Chinese Communist Party has learned this lesson about the nature of religion, belief, and magic. ${ }^{18}$ The use and manifestation of jingshen in Chinese communism has much in common with the deployment of magical power in religion. Like magical power, jingshen compels supernatural forces to behave in a certain way in order to achieve specific and desired effects in the natural world. In doing so, it impels what Lévi-Strauss called 'at least a trace' (1966: 221) of belief in its religion: communism. As a consequence, the Party is already well underway in shaping its evolution from just an infallible bearer of ideological truth to becoming a sacred object of worship and source of magical power as well. Put differently, just when the Party's ideology is losing its appeal as a quasi-religious dogma, so do the Party and its rule start to mimic a religious institution for which dogma paradoxically matters much less.

\section{Conclusion}

The vacuity of the CCP's ideology has compelled the CCP to explore new bases for the legitimacy of its rule. In its search, it has turned to religion too. As we have seen in this article, the Party delves into its own past in ways that are replete with religious language and methods that turn profane might into sacred rule. The old concept of party spirit has been revamped and the Party has started to use the repertoire of heritage, tourism, and pilgrimage to create a commodified magical power that charges the Party and its rule with a sacred 
nature. However, religious thought has no place here. Instead, religious and magical practices serve as an additional source of neo-socialist governmental techniques.

This, I submit, is no coincidence. It is part of a deliberate attempt to turn the Party itself rather than its ideology and mission into a sacred entity and an object of religious awe. As already intimated at the start of this article, this practical deployment of the sacred is, in fact, not all that dissimilar to the use of Christian ideas and practices in the 'civil religion' of the United States. The secularist separation between church and state and the disconnect between state and citizen have left a disenchanted gap at the core of modern Western societies. State, church, society, and individual have been separated from each other without anything that naturally binds them together. Adopting aspects of religion for a strictly secular worship of the nation has been one way to tie nation, state, and society back together again (Bellah 1967; Robertson 1978, chap. 5).

However, as recent work has shown, the ideology of secularism is quite distinct from the actual social process of secularization whereby religion is hived off from other spheres of society. Processes of secularization are both historically contingent and culturally specific and can therefore have very dissimilar outcomes. It would be wrong to take as the norm the Western European pattern that combines a secular state with the general decline of religious belief and institutions in society. Secularization in, for instance, the United States or India follows very different patterns whereby an explicit secularism of the state goes together with the growth and revival of religion in society and even in politics (Asad 2003; Calhoun, Juergensmeyer \& VanAntwerpen 2011; Casanova 1994; Hann 2010; Taylor 2007; van der Veer 2001).

Party spirit and party essence should be read as part of the CCP's answer to the global crisis of secularism, which it shares. Secularism is an ideology with strong Western roots that is found all over the world as part of the hegemony of modernization as a universal human 
project. Communist atheism is an extreme form of secularism. To achieve socialist modernity, communism wishes to purge society of the superstitions and falsehoods of all forms of religion, which merely serve to mask exploitation and oppression. The Party's communist secularism was inflected by - and was frequently even at odds with - long-term culturally specific processes of secularization of society and politics (Goossaert \& Palmer 2011; Madsen 2011; Ngo \& Quijada 2015; Zhe 2015). The roots of Chinese secularization include, but run much deeper than, the secular nature of Confucianism (G.W. Wang 2003) and the imperial and communist distinction between, on the one hand, politically subversive religions and movements that are to be suppressed and, on the other, politically harmless religions and practices that can be tolerated (Brook 2010). From the Northern Song dynasty (960-1127 CE) onwards, the imperial state actively involved itself in sanctioning and transforming popular religious cults. By 'standardizing the gods' (Watson 1986), the state made itself much more directly visible and present in local communities as both a secular and a religious power. Not only did gods come to resemble officials, generals, emperors, or empresses, but the state also gave (or withdrew again) its official sanction of popular cults by bestowing titles and ranks on gods in much the same way as on worldly officials. As many anthropologists and historians have observed, the political-religious hegemony of the imperial state was such that the pantheon of gods continued to resemble the imperial bureaucracy long after the end of the Qing Empire in 1911 (Duara 1988; Feuchtwang 2001; A. Wolf 1978).

Imperial China's specific trajectory of secularization therefore did not simply separate religion from the state. Secular and religious power and authority were in fact welded together even more closely, but on strictly secular terms. Secular state power was the source of religious legitimacy, while religious practices in turn reinforced the authority of the state. The secular sanction of religion had nothing to do with belief or dogma, but merely with the political orthodoxy of religious practices. By keeping belief out of the equation, the state gave 
itself the space to create religious practices in its own, secular image, despite the disdain for such idolatry from Confucian scholars. Chinese secularization thus puts the worldly power of the state above any religious authority, but does so by keeping the world fully enchanted: Chinese society and the state remained suffused with magic and supernatural forces.

Blinded by communist atheism and its wholesale modernist rejection of traditional culture, the CCP has ignored the enchanted power and legitimacy that religion might have given its rule. However, things are beginning to look different now. The deployment of red tourism and cadre education shows that the $\mathrm{CCP}$ is now learning that the state in China can and perhaps even must be supported by religious power. The magic of party spirit in contemporary China can thus be read as a component of a long-term strategy to 're-enchant' (Gellner 2005 [1959]) Chinese communist modernity in the production of a dedication to the Party that is secular and religious at the same time. This I propose to call a Chinese communist civil religion. It must be emphasized that this communist civil religion is not simply a return to Maoist ideology and Maoist dictatorial rule. It uses some of the language and images of China's Maoist past, but in the context of a highly commercialized economy, a much more autonomous society, and neo-socialist rule. It is also much more than the propagandistic use of modern marketing and public relations techniques that aim at old-fashioned 'thought management' and popular support.

Communist civil religion does not just target the secular mind. By putting magic back into the world, it speaks directly to the heart. The construction of a communist civil religion is part of a long-term reorientation of the basis of CCP rule that draws on an eclectic range of sources and ideas, both Chinese and Western. The unique contribution of a communist civil religion to this grand project is that it naturalizes the Party's rule, making it unquestioned and unquestionable. If successful, the communist civil religion might in the long term excuse the 
Party from even having an ideology or ultimate mission at all. The Party will then no longer have to be believed. It will simply be believed in.

\section{NOTES}

* I would like to thank Gregor Benton, Bill Callahan, Vincent Chang, Alka Shah, Tabitha Speelman, Danie Stockmann, Jonathan Unger, Maghiel van Crevel, Zhang Ruilan, and the three anonymous reviewers for their comments and suggestions. Earlier versions were presented at the East Asian Institute of the National University of Singapore, the Leiden University Institute of Area Studies, and SOAS in London.

${ }^{1}$ Central Party Archives (1991: 31, 33-4) Later on in 1941, the CCP Politburo issued a formal decision on strengthening party spirit: Central Politburo of the CCP, Decision of the Party centre on strengthening Party spirit (Zhonggong Zhongyang guanyu zengqiang dangxing de jueding), 1 July 1941. I am grateful to Zhang Ruilan for bringing these sources to my attention.

${ }^{2}$ For an excellent case study of the development and political vicissitudes of the site of the First Party Congress in Shanghai in 1921, see Ho (2016).

${ }^{3}$ In 2005, a new batch of sixty-six patriotic education model bases was announced, with a further batch of eighty-seven sites added in 2009 (People's Web 2009 -news website run by the official party newspaper People's Daily).

${ }^{4}$ On-site learning does not occur in the 2013-17 national plan itself, but is mentioned in local documents. One such document that happens to be freely available on the web is the CCP Jinan City Committee Document No. 7 (CCP Jinan City Committee 2014). 
${ }^{5}$ Interviews, Beijing, 27-8 April 2007; fieldnotes, Beijing, 17 December 2006. See also People's Web (2005); Shambaugh (2008: 148-9).

${ }^{6}$ Fieldnotes, Chongqing, 3 July 2015.

${ }^{7}$ Fieldnotes, Chongqing, 1-2 July 2015.

${ }^{8}$ The narrative summarized in the paragraph has been taken from a paper written by Chongqing's former head of propaganda (Zhou 2015). Similar narratives are produced in the many textbooks and other teaching materials used in Hongyan for the education of visiting cadres.

${ }^{9}$ Fieldnotes, 2 July 2015.

${ }^{10}$ The novel Hongyan has been translated into English (see Lo \& Yang 1978). On SACO itself, see Mitter (2013: 286-9). For a critical discussion of SACO's alleged involvement in torture, see Eberlein (2011).

${ }^{11}$ On Gele Mountain, White Villa, and Refuse Pit, see Y.P. Li et al. (2010). Further information was obtained from Zhou Yong, pers. comm., 24 July 2015. On the new hall completed in 2008, see W.L. Li, Li, Yang \& Li (2008).

${ }^{12}$ Fieldnotes, Chongqing, 2 July 2015.

${ }^{13}$ On the purchase of photos, see Zhongguo xinwen wang (2009).

${ }^{14}$ For a partisan account of the Chongqing model by a prominent public intellectual in Beijing, see Cui (2011).

${ }^{15}$ After his fall, Bo Xilai's time in Chongqing has been cleansed from the Chinese Internet and there is hardly a trace left of his endorsement of Hongyan and Li Hua. The description here is therefore largely based on a personal communication from a foreign resident of 
Chongqing at the time, and an article written by a former native of Chongqing in the magazine The Atlantic (Eberlein 2011).

16 The effort to document and research Chongqing's wartime history was also started under Bo Xilai in May 2008. It includes a total investment of 150 million yuan in the restoration of a total of 108 historic sites, including Kuomintang buildings and the museums at Hongyan village discussed in this article (Zhou, Chang \& Gong 2014; fieldnotes, 1 July 2015).

${ }^{17}$ I have translated the term dangde xingzhi literally as 'the party's nature'. An alternative rendition would be to interpret it as the full form of dangxing (party spirit). This is, however, less likely. Dangde xingzhi (party's nature), as referred to by Xi Jinping here, seems to inhere exclusively in the party itself, whereas dangxing (party spirit) is shared between the party and its cadres, members and followers, through, as I am arguing in this article, the magical mediation of jingshen (party essence).

${ }^{18}$ The authorities in the Soviet Union had been aware of the importance of constructing a socialist ritual life much earlier (see Lane 1981). 


\section{REFERENCES}

ARON, R. 1957. The opium of the intellectuals (trans. T. Kilmartin). London: Secker \& Warburg.

ASAD, T. 2003. Formations of the secular: Christianity, Islam, modernity. Stanford: University Press.

BADONE, E. \& S.R. RosEMAN 2004. Approaches to the anthropology of pilgrimage and tourism. In Intersecting journeys: the anthropology of pilgrimage and tourism (eds) S.R. Roseman \& E. Badone, 1-23. Urbana: University of Illinois Press.

BARMÉ, G.R. 1999. In the red: on contemporary Chinese culture. New York: Columbia University Press.

BeLLAH, R.N. 1967. Civil religion in America. Daedalus 96, 1-21.

BENTON, G. 1999. New Fourth Army: communist resistance along the Yangtze and the Huai, 1938-1941. Berkeley: University of California Press.

BourdiEU, P. 1977. Outline of a theory of practice (trans. R. Nice). Cambridge: University Press. 
BROOK, T. 2010. The politics of religion: late-imperial origins of the regulatory state. In Making religion, making the state (eds) Y. Ashiwa \& D.L. Wank, 22-42. Stanford: University Press.

Calhoun, C., M. Juergensmeyer \& J. VanAntwerpen (eds) 2011. Rethinking secularism. Oxford: University Press.

Callahan, W.A. 2010. China: the pessoptimist nation. Oxford: University Press.

Casanova, J. 1994. Public religions in the modern world. Chicago: University Press.

CCP Jinan City CommitTee 2014. CCP Jinan City Committee Document no 7, 2014, Opinion of the CCP Jinan City Committee on the implementation of the 2013-2017 national cadre training plan [Zhonggong Jinan shiwei wenjian (2014) 7 hao, Zhonggong Jinan shiwei guanyu guanche luosho $<<2013-2017$ nian quanguo ganbu jiaoyu peixun guihua >> de shishi jianyi], 5 May (available on-line: www.jnsw.gov.cn/icms_responsepic.aspx?fjid=11271, accessed 18 June 2015).

Central Party ArChives 1991. Collection of documents of the CCP Centre [Zhonggong Zhongyang wenjian xuanji], vol. 13. Beijing: CCP Central Party School Publishing House [Zhonggong Zhongyang Dangxiao Chubanshe]. 
China NATIONAL Tourism AdMINISTRATION 2014. National coordinating small group for red tourism work convenes its twelfth meeting in Beijing [Quanguo hongse lüyou gongzuo xietiao xiaozu dishi'er ci huiyi zai Jing zhaokai]. China National Tourism Administration [Guojia Lüyou Ju] website, 20 February (available on-line http://www.cnta.gov.cn/jgjj/jgsz/sszwz/qghslygzxtxz/gzdt/201507/t20150720_742378.shtml, accessed 22 January 2016).

2015. National Coordinating Small Group for Red Tourism work convenes its thirteenth meeting in Beijing [Quanguo hongse lüyou gongzuo xietiao xiaozu dishisan ci huiyi zai Jing zhaokai]. China National Tourism Administration [Guojia Lüyou Ju] website, 3 February (available on-line http://www.cnta.gov.cn/jgjj/jgsz/sszwz/qghslygzxtxz/gzdt/201507/t20150720_742379.shtml, accessed 21 January 2016).

COHEN, E.H. 2006. Religious tourism as an educational experience. In Tourism,religion and spiritual journeys (eds) D.J. Timothy \& D.H. Olsen, 78-93. London: Routledge.

Coleman, S. 2002. Do you believe in pilgrimage? Anthropological Theory 2, 355-68.

2015. Anthropological tropes and historical tricksters: pilgrimage as an 'example' of persuasion. Journal of the Royal Anthropological Institute (N.S.) 21, 144-61. 
CuI, Z.Y. 2011. Partial intimations of the coming whole: the Chongqing experiment in light of the theories of Henry George, James Meade, and Antonio Gramsci. Modern China 36, 646-60.

DENG, X.P. 1983. Sixiang luxian zhwengzhi luxiande shixian yao kao zuzhi luxian lai baozheng [Realizing the ideological line and the political line will depend on the guarantee of the organizational line]. Speech of Deng Xiaoping at the enlarged conference of the standing committee of the naval committee of the Chinese Communist Party, 29 July 1979. In Deng Xiaoping wenxuan [Selected works of Deng Xiaoping], vol. 2, 190-3. Beijing: Renmin Chubanshe.

DENTON, K.A. 2014. Exhibiting the past: historical memory and the politics of museums in postsocialist China. Honolulu: University of Hawai'i Press.

DUARA, P. 1988. Superscribing symbols: the myth of Guandi, Chinese god of war. Journal of Asian Studies 47, 778-95.

DURKHEIM, É. 1965 [1912]. The elementary forms of the religious life (trans. J.W. Swain). New York: Free Press.

EADE, J. \& M.J. SALLNOW 1991. Introduction. In Contesting the sacred: the anthropology of Christian pilgrimage (eds) J. Eade \& M.J. Sallnow, 1-29. London: Routledge. 
EBERLEIN, X.J. 2011. Another kind of American history in Chongqing, 4: Explorers; and 5: revision. The Atlantic website, 3-4 February 2011 (available on-line https://www.theatlantic.com/international/archive/2011/02/another-kind-of-americanhistory-in-chongqing-4-explorers/70708/ and http://www.theatlantic.com/international/archive/2011/02/another-kind-of-americanhistory-in-chongqing-5-revision/70787/, accessed 3 August 2018).

ElIADE, M. 1958. Sacred places: temple, palace, 'centre of the world'. In Patterns in comparative religion, 367-85. London: Sheed \& Ward.

EVANS-PRITCHARD, E.E. 1965. Theories of primitive religion. London: Oxford University Press

FEUCHTWANG, S. 2001. The imperial metaphor: popular religion in China. London: Routledge.

GELLNER, E. 2005 [1959]. Introduction: the saltmines of Salzburg or Wittgensteinianism reconsidered in historical context. In Words and things: an examination of, and an attack on, linguistic philosophy, 1-44. London: Routledge.

Goossaert, V. \& D.A. PALMER 2011. The religious question in modern China. Chicago: University Press. 
GRABURN, N.H.H. 1977. Tourism: the sacred journey. In Hosts and guests: the anthropology of tourism (ed.) V.L. Smith, 17-31. Philadelphia: University of Pennsylvania Press.

GREENWOOD, S. 2009. The anthropology of magic. Oxford: Berg.

GUANGMING DAILY 2014. Scientific guide to open up the development the new realm of red tourism [Kaipi hongse lüyou fazhan xin jingjiede kexue zhinan]. Guangming Daily [Guangming Ribao], 28 November.

HANN, C. 2010. Broken chains and moral lazarets: the politicization, juridification and commodification of religion after socialism. In Religion, identity, postsocialism: the Halle Focus Group 2003-2010 (ed.) C. Hann, 3-21. Halle: Max Planck Institute for Social Anthropology.

HARRIS, R. 1999. Lourdes: body and spirit in the secular age. London: Penguin.

HEWISON, R. 1987. The heritage industry: Britain in a climate of decline. London: Methuen.

Ho, D.Y. 2016. Making a revolutionary monument: the site of the First National Congress of the Chinese Communist Party. In Red legacies in China: cultural afterlives of the communist revolution (eds) J. Li \& E.H. Zhang, 25-55. Cambridge, Mass.: Harvard University Asia Center. 
HubBert, J. 2006. (Re)collecting Mao: memory and fetish in contemporary China. American Ethnologist 33, 145-61.

LANE, C. 1981 The rites of rulers: ritual in industrial society - the Soviet case. Cambridge: University Press.

LEE, C. 2015. Training the party: party adaptation and elite training in reform-era China. Cambridge: University Press.

LEESE, D. 2011. Mao cult: rhetoric and ritual in China's Cultural Revolution. Cambridge: University Press.

LÉvi-Strauss, C. 1966. The savage mind. Chicago: University Press.

LI, H. 2004. 'Hongyan' goes commercial ('Hongyan' xia hai). Red China Net (Zhong hong wang), 10 December (available on-line http://www.crt.com.cn/news2007/News/lihua/20065/30/00008659.html, accessed 30 September 2015).

LI, J. \& E.H. ZHANG (eds) 2016. Red legacies in China: cultural afterlives of the communist revolution. Cambridge, Mass.: Harvard University Asia Center. 
LI, W.L., M.X. LI, Y. YANG \& F.L. Li 2008. The completely new face of the Hongyan Soul Exhibition Hall [Chongqing Hongyanhun xin chenlie zongguan quanxin liangxiang]. Xinhua Net (Xinhuawang) website, 9 July (available on-line http://www.crt.com.cn/news2007/News/jryw/2008/79/0879142638195I62FJE0K57KD1D0 EB.html, accessed 3 August 2018).

LI, Y.P., Z.Y. HU \& C.Z. ZHANG 2010. Red tourism: sustaining communist identity in a rapidly changing China. Journal of Tourism and Cultural Change 8, 101-19.

LIU, G.L. 2014. Central Party School lists the Guizhou education base [Zhongyang dangxiao Guizhou jiaoxue jidi guapai]. Study Times [Xuexi Shibao], 26 May.

Lo, K.-P. \& Y.-Y. YANG 1978. Red crag, Beijing: Foreign Languages Press.

MacFARQUHAR, R. \& M. Schoenhals 2006. Mao's last revolution. Cambridge, Mass.: Belknap Press of Harvard University Press.

MAdSEN, R. 2011. Secularism, religious change, and social conflict in Asia. In Rethinking secularism (eds) C. Calhoun, M. Juergensmeyer \& J. VanAntwerpen, 248-69. Oxford: University Press.

MITTER, R. 2013. China's war with Japan, 1937-1945: the struggle for survival. London: Penguin. 
NATIONAL DEVELOPMENT AND REFORM COMMISSION 2004. Outline of the red tourism development plan for the years 2004 to 2010 [2004-2010 nian quanguo hongse lüyou fazhan guihua gangyao 2004-2010]. National Development and Reform Commission [Guojia Fazhan he Gaige Weiyuanhui] website, n.d. (available on-line http://www.sdpc.gov.cn/fzgggz/fzgh/ghwb/gjjgh/200709/P020150630514113129776.pdf, accessed 3 August 2018).

NGO, T.T. T. \& J.B. QUIJADA 2015. Introduction: atheist secularism and its discontents. In Atheist secularism and its discontents: a comparative study of religion and communism in Eurasia (eds) T.T.T. Ngo \& J.B. Quijada, 1-26. Houndmills: Palgrave Macmillan.

PEOPLE'S DAILY 2014. To grasp work style party spirit must first be strengthened [Zhua zuofeng bi xian qiang dangxing]). People's Daily (Renmin Ribao), 20 March.

People's Web 2005. Training classes at the three cadre academies innovate the model of training for party and state leading cadres [San suo ganbu xueyuan peixunban chuangxin dangzheng lingdao ganbu peixun moshi]. People's Web [Renmin Wang] website, 4 August (available on-line http://politics.people.com.cn/GB/8198/60906/61581/4269456.html, accessed 3 August 2018). 
2009. National patriotic education model bases [Quanguo aiguozhuyi jiaoyu mofan jidi]. People's Web (Renminwang) website, n.d. (available on-line http://dangshi.people.com.cn/GB/151935/157318/, accessed 3 August 2018).

2013. 2013-2017 national cadre education and training plan [2013-2017 nian quanguo ganbu jiaoyu peixun guihua]. People's Web [Renmin wang] website, 29 September (available on-line: http://politics.people.com.cn/n/2013/0929/c100123069508.html, accessed 20 July 2015).

PHILLIPS, T. 2015. Communist party theme park sparks ridicule among chinese internet users. Guardian, 1 October (available on-line:

https://www.theguardian.com/world/2015/oct/01/communist-party-theme-park-sparksridicule-among-chinese-internet-users, accessed 3 August 2018).

PIEKE, F.N. 2009. The good communist: elite training and state building in today's China. Cambridge: University Press.

2016. Knowing China: a twenty-first-century guide. Cambridge: University Press.

ROBERTSON, R. 1978. Meaning and change: explorations in the cultural sociology of modern societies. Oxford: Basil Blackwell. 
SANGREN, P.S. 1987. History and magical power in a Chinese community. Stanford:

University Press.

SHAMBAUGH, D. 2008. China's communist party: atrophy and adaptation. Washington, D.C.:

Woodrow Wilson Center Press; Berkeley: University of California Press.

2015. The coming Chinese crackup. The Wall Street Journal, 6 March (available online: https://www.wsj.com/articles/the-coming-chinese-crack-up-1425659198, accessed 3 August 2018).

SHEPHERD, R.J. \& L. YU 2013. Heritage management, tourism, and governance in China: managing the past to serve the present. New York: Springer.

SORACE, C. 2016. Party spirit made flesh: the production of legitimacy in the aftermath of the 2008 Sichuan earthquake. The China Journal 76, 1-22.

STYERS, R. 2004. Making magic: religion, magic, and science in the modern world. Oxford: University Press.

TAKAYAma, Y. 2012. Red tourism in China. In India, Russia, China: comparative studies on Eurasian culture and society (eds) T. Mochizuki \& S. Maeda, 113-30. Sapporo: Slavic Research Center, Hokkaido University. 
TAYLOR, C. 2007. A secular age. Cambridge, Mass.: Harvard University Press.

TURNER, V. \& E. TURNER 1978. Image and pilgrimage in Christian culture. New York: Columbia University Press.

VAN DER VEER, P. 2001. Imperial encounters: religion and modernity in India and Britain. Princeton: Princeton University Press.

WANG, G.W. 2003. Secular China. China Report 39, 305-21.

WANG, H. 2014. Research on the ecological transformation and upgrading of red tourism in China [Zhongguo hongse lüyou shengtaihua zhuanxing shengji yanjiu]. Xiangtan: Xiangtan Daxue Press.

WANG, H.Z. 2011. Tourism flourishing as more delve into the past. China Daily, 26 June.

WANG, S.M. \& G.P. LIU 2014. Scientific guide to open up the development of a new realm of red tourism [Kaipi hongse lüyou fazhan xin jingjiede kexue zhinan]. Guangming Daily [Guangming Ribao], 28 November.

WATSON, J.L. 1986. Standardizing the gods: the promotion of T'ien Hou ("Empress of Heaven") along the South China coast, 960-1960. In Popular culture in late imperial 
China David Johnson, Andrew J. Nathan and Evelyn S. Rawski (eds), 292-324. Berkeley: University of California Press.

Weber, M. 1946. Science as a vocation. In From Max Weber: essays in sociology (eds) H.H. Gerth \& C. W. Mills, 129-56. New York: Oxford University Press.

Wolf, A. 1978. Gods, ghosts, and ancestors. In Studies in Chinese society (ed.) A. Wolf, 13283. Stanford: University Press.

WoLF, E. 1958. The virgin of Guadalupe: a Mexican national symbol. Journal of American Folklore 71,34-9.

XU, R. 2010. Research on China's red tourism [Zhongguo hongse lüyou yanjiu]. Beijing: Zhongguo Jinrong Press.

YAN, Y.X. 2009. The Good Samaritan's new trouble: a study of the changing moral landscape in contemporary China. Social Anthropology 17, 9-24.

YU, X.C. 2013. Poems from China's red tourism scenic spots [Zhongguo hongse mingsheng lïyou shihua]. Beijing: Zhongguo Wenshi Press. 
ZHAO, S.S. 1998. A state-led nationalism: the patriotic education campaign in postTiananmen China. Communist and Post-Communist Studies 31, 287-302.

ZHE, J. 2015. Secularization without secularism: the political-religious configuration of post1989 China. In Atheist secularism and its discontents: a comparative study of religion and communism in Eurasia (eds) T.T.T. Ngo \& J.B. Quijada, 92-111. Houndmills: Palgrave Macmillan.

ZHONGGUO XINWEN WANG 2009. Chongqing zhongjin goumai kangzhan lao zhaopian fuyin shiyongquan yin zhengyi [Chongqing's high-price purchase of the use rights of offprints of old pictures from the wartime period incites dispute], 13 April (available on-line: http://media.people.com.cn/GB/40606/9117970.html, accessed 8 August 2018).

ZHOU, Y. 2015. Contributions of Hongyan's essence to China's revolutionary essence and its contemporary value [Hongyan jingshen dui Zhongguo geming jingshende gongxian ji shidai jiazhi]. Unpublished paper.

, V.K.L. CHANG \& X.H. Gong 2014. Recalling the war in China: the dahoufang project in Chongqing and the restoration of a legacy. Frontiers of History in China 9, 61127.

Frank N. Pieke taught anthropology and Chinese studies in Leiden and Oxford. In 2018, he was appointed research director and CEO of the Mercator Institute for China Studies 
(MERICS) in Berlin. His most recent books (both for Cambridge University Press) are Knowing China (2016) and The good communist (2009).

Mercator Institute of Chinese Studies, Klosterstrasse 64, 10179 Berlin, Federal Republic of Germany.frank.pieke@merics.de 